\title{
Perbedaan Persepsi Harapan antara Keluarga dan Lansia tentang Pemenuhan Kebutuhan Lansia Selama Tinggal Bersama
}

\author{
Achir Yani S. Hamid*, Rislah Dibah**
}

\begin{abstract}
Abstrak
Penelitian ini bertujuan menguraikan perbedaan persepsi keluarga dan lansia tentang pemenuhan kebutuhan lansia selama mereka tinggal bersama. Sampel terdiri dari tiga puluh keluarga (anak/menantu wanita Lansia) dan 30 Lansia wanita yang dipilih secara purposive dan tinggal dalam satu rumah. Hasil penelitian menunjukkan perbedaan yang besar antara harapan keluarga dengan Lansia dalam hampir semua pemenuhan kebutuhan Lansia, kecuali kebutuhan spiritual.
\end{abstract}

Kata kunci: adaptasi, ketergantungan, kesenjangan persepsi dukungan keluarga.

\begin{abstract}
The purpose of this research was to describe the different perception of expectation between the family and the elderly concerning their needs. Thirty families (daughter daughter in law) and 30 Elderly women who were pusposefully selected and stayed at the same house. The result of this study revealed that there were different expectations as perceived by families and the elderly woman for all aspects of the elderly needs expect for spiritual needs.
\end{abstract}

Key word: adaptation, dependency, different perception family support. 